\title{
Endoscopic stricturotomy for a refractory complex esophageal stricture
}

Benign esophageal strictures present a frequent endoscopic challenge [1-4]. Endoscopic stricturotomy using an electrocautery technique is effective for simple or short strictures $(<1 \mathrm{~cm})[5]$; however, there are few reports of its application for complex or long (>1 cm) esophageal strictures.

A 69-year-old man presented to our institution with dysphagia and a complex benign distal esophageal stricture. He was initially treated with three serial endoscopic balloon dilations up to $12 \mathrm{~mm}$, followed by placement of an esophageal stent. Following removal of the stent, the patient developed recurrence of the distal esophageal stricture. He was evaluated by the thoracic surgery team for possible distal esophagectomy, but was deemed a high risk surgical candidate.

On repeat endoscopy ( $\triangleright$ Video 1 ), a severe stenosis was noted at $34 \mathrm{~cm}$ from the incisors ( $\triangleright$ Fig.1), measuring $1 \mathrm{~mm}$ in diameter and $4 \mathrm{~cm}$ in length ( $\triangleright$ Fig. 2 ). A submucosal injection of methylene blue and saline solution proximal to the stricture was used to create a cushion to perform the stricturotomy ( $\mathbf{F i g} \cdot \mathbf{3 a}$ ). The stenosis was first carefully incised with a dissection knife, initially the IT2 (Olympus, Tokyo, Japan) and then the DualKnife (Olympus, Tokyo, Japan), using a combination of Endocut $Q$ and forced coagulation. A guidewire was passed through the pinhole opening, delineating the esophageal lumen. We continued to incise the fibrotic tissue of the stenosis carefully in layers, until it was possible to pass the gastroscope though

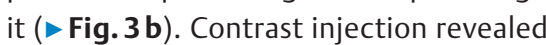
no leakage and improved passage of the contrast into the gastric body. To allow for esophageal remodeling, the distal esophagus was then stented with a $23 \times$ 100-mm EndoMAXX fully covered stent

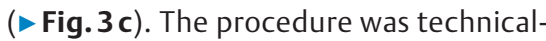

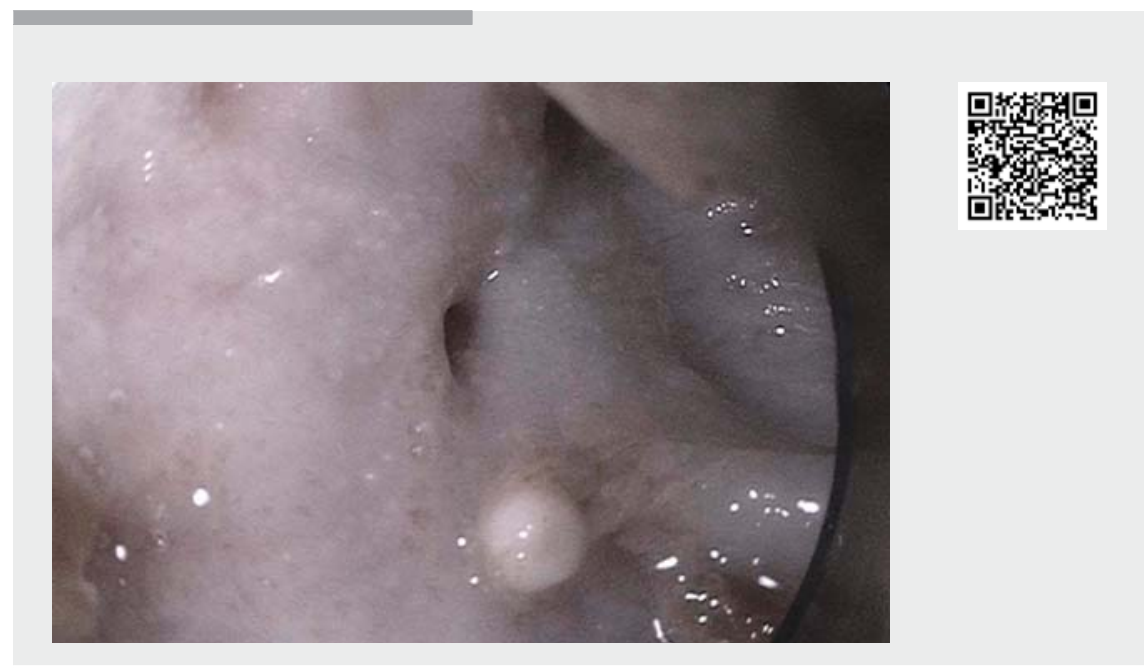

$\checkmark$ Video 1 Endoscopic stricturotomy using an electrocautery technique for a refractory complex distal esophageal stricture.

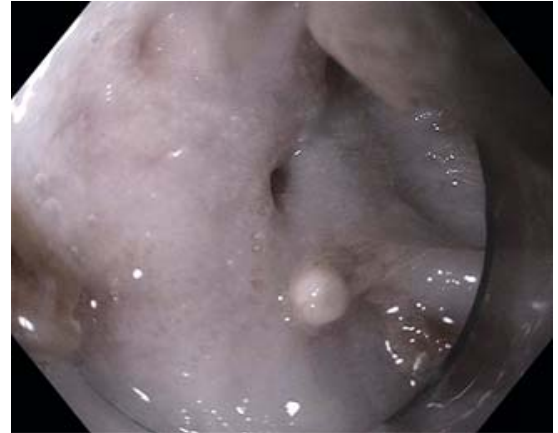

Fig. 1 Endoscopic image showing severe esophageal stenosis at $34 \mathrm{~cm}$ from the incisors.

ly successful and there were no adverse events. During follow-up at 3 weeks, the patient reported tolerating an oral solid diet without recurrence of symptoms. Endoscopic stricturotomy appears technically feasible and may prove a useful

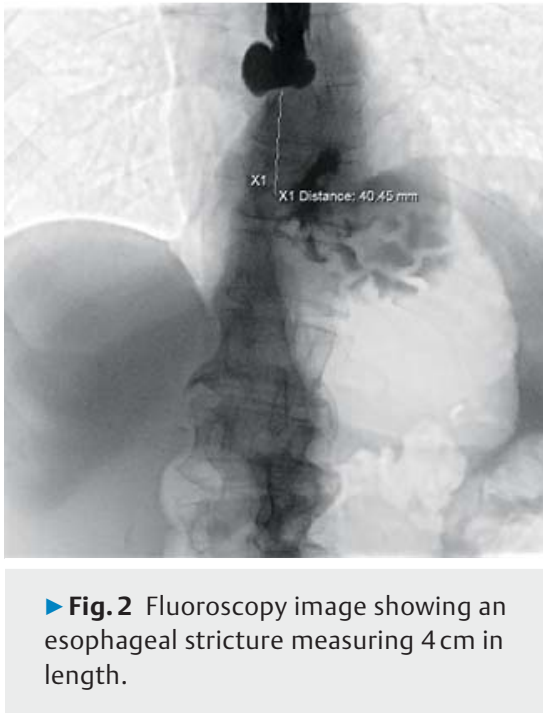

treatment for refractory and complex endoscopic strictures.

Endoscopy_UCTN_Code_TTT_1AO_2AD 

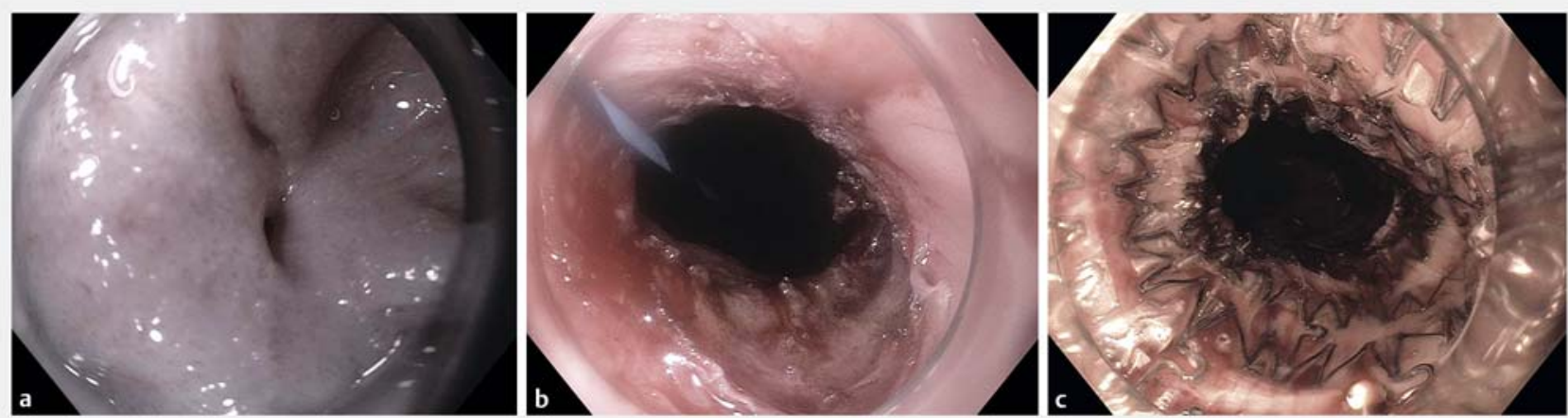

- Fig.3 Endoscopic images showing: a the esophageal stricture following submucosal injection of methylene blue and normal saline solution in a four-quadrant fashion; $\mathbf{b}$ the stricture following incision in the four quadrants; $\mathbf{c}$ the fully covered esophageal stent in position following stricturotomy.

\section{Competing interests}

The authors declare that they have no conflict of interest.

\section{The authors}

Amit Mehta, Shawn L. Shah, Srihari Mahadev New York Presbyterian Hospital/Weill Cornell Medical Center, New York, New York, USA

\section{Corresponding author}

\section{Srihari Mahadev, MD}

Department of Medicine, Division of Gastroenterology and Hepatology, 1283 York Avenue, 9th Floor, New York, NY 10065, USA

srm9005@med.cornell.edu

\section{References}

[1] Repici A, Small A], Mendelson A et al. Natural history and management of refractory benign esophageal strictures. Gastrointest Endosc 2016; 84: 222-228

[2] Ramage JI Jr, Rumalla A, Baron TH et al. A prospective, randomized, double-blind, placebo-controlled trial of endoscopic steroid injection therapy for recalcitrant esophageal peptic strictures. Am J Gastroenterol 2005; 100: $2419-2425$

[3] Fuccio L, Hassan C, Frazzoni L et al. Clinical outcomes following stent placement in refractory benign esophageal stricture: a systematic review and meta-analysis. Endoscopy 2016; 48: 141-148

[4] Siersema PD. How to Approach a patient with refractory or recurrent benign esophageal stricture. Gastroenterology 2019; 156: 7-10

[5] Simmons DT, Baron TH. Electroincision of refractory esophagogastric anastomotic strictures. Dis Esophagus 2006; 19: 410 414
Bibliography

Endoscopy 2021; 53: E181-E182

DOI $10.1055 / \mathrm{a}-1230-3008$

ISSN 0013-726X

published online 2.9.2020

(c) 2020. Thieme. All rights reserved.

Georg Thieme Verlag KG, Rüdigerstraße 14,

70469 Stuttgart, Germany

\section{ENDOSCOPY E-VIDEOS \\ https://eref.thieme.de/e-videos}

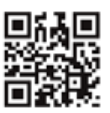

Endoscopy E-Videos is a free access online section, reporting on interesting cases and new

techniques in gastroenterological endoscopy. All papers include a high quality video and all contributions are freely accessible online.

This section has its own submission website at

https://mc.manuscriptcentral.com/e-videos 